Original paper

\title{
Dominant benthic mollusks in closed atolls, French Polynesia
}

\author{
Bernard SALVAT*
}

USR 3278 CNRS-EPHE-CRIOBE - Université de Perpignan, BP 1013 Moorea 98.729, French Polynesia

Corresponding author: B. Salvat

E-mail: bsalvat@univ-perp.fr

Communicated by Makoto Tsuchiya

\begin{abstract}
We investigated the mollusk fauna of 53 closed lagoons (atolls without passes) among the 83 French Polynesian atolls. These confined lagoons of closed atolls reveal a limited diversity of mollusks but with wide distribution of some species. A few species occur in these lagoons but each lagoon is unique with a particular qualitative mollusk composition related to only 5 species: Tridacna maxima, Pinctada margaritifera, Pinctada maculata, Chama iostoma and Arca ventricosa. Due to the absence or poor data on 14 closed lagoons, our detailed study was limited to 39 . We characterised the mollusk fauna of each closed lagoon and attempted to identify group of lagoons with the same dominant mollusk composition. T. maxima, the giant clam, appeared to be the most characteristic species of these confined lagoons with large densities and populations in 32 of the 39 lagoons. P. margaritifera, the mother-of-pearl oyster, also occurs as large populations in 18 lagoons; these two species are of economic importance now as they were in the past. The three other species mentioned above occurred respectively in 25, 28 and 20 lagoons. There are 11 lagoons with original and unique characteristics (their assemblages of dominant species do not occur in any other lagoon), 28 are grouped in 7 categories of assemblages. The most numerous groups contain all 5 species or at least 4 of them. Research topics are suggested in order to understand the ability of each mollusk species to colonize and maintain its dominance in a confined lagoon.
\end{abstract}

Keywords coral reefs, atolls, closed lagoons, benthic fauna, mollusks

\section{Introduction}

French Polynesia is located in the eastern part of the South Pacific. The Exclusive Economic Zone (5.5 millions $\mathrm{km}^{2}$ ) extends from $5^{\circ}$ to $30^{\circ}$ south latitude and $130^{\circ}$ to $160^{\circ}$ west longitude, and includes 5 archipelagos with 118 islands, 34 being volcanic basaltic islands and 83 being low coral islands or atolls, and 1 sand bank. The Society archipelago ( 9 volcanic islands and 5 atolls), the Tuamotu archipelago (76 atolls) and the Gambier archipelago (8 volcanic islands and 1 atoll) form a continuity from west to east between $14^{\circ}$ and $24^{\circ}$ south latitude. To the north, the Marquesas archipelago (11 volcanic islands and 1 sand bank) lies between $8^{\circ}$ and $11^{\circ}$ south latitude while the Austral archipelago (5 volcanic islands and 1 atoll) is between $22^{\circ}$ to $28^{\circ}$ latitude south in the subtropical zone.

All these islands are oceanic and formed by past or recent volcanic activity. The sea floor on which the French Polynesia islands are emerging was formed between 25 and 85 million years ago by the spread of sea-floor along the ancient Pacific-Farallon ridge (Bonneville 2009) near the East Pacific Ridge. The Society, Marquesas, Austral and Gambier islands were formed by seismic hot spot 
activity in less than 20 million years with islands emerging from the sea floor more than $4000 \mathrm{~m}$ deep. According to their origin by the hot spot, the islands of these archipelagos are drifting to the north-northwest at a speed of about 10 $\mathrm{cm} /$ year and are also subsiding. In these archipelagos, the more southeast islands are the youngest whereas the northwest ones are the oldest. The Tuamotu Archipelago is only constituted of atolls, with a very thick cover of coral reef construction on a basalt basement, which is elevated from the plateau and has been drifting northnorthwest for many million years. Some islands in the south of the Tuamotu Archipelago belong to the chain due to the hotspot, near Pitcairn (United Kingdom) which is the origin of the Gambier Islands and also Mururoa and Fangataufa (where nuclear testing by France was conducted) until Duke of Gloucester Islands and Hereheretue atolls, as far as $15^{\circ}$ latitude north-northwest from the Pitcairn hotspot (Salvat et al. 2008)

Tahiti is the main island of French Polynesia (1051 $\mathrm{km}^{2} ; 2241 \mathrm{~m}$ altitude). Most high volcanic islands in the Society, Gambier and Austral archipelagos are surrounded by coral reef ecosystems. Moorea, the sister island of Tahiti, is well known for its reefs following scientific research conducted by the CRIOBE-EPHE research center located on the island. In the Austral Archipelago, Rapa has neither coral reefs nor a lagoon because of its subtropical, latitudinal, position where sea surface temperatures are too low. Nevertheless, Rapa submarine habitats contain scleractinians which show many coral reef species with a high degree of endemism. The Marquesas Islands have neither reefs nor lagoons because coral reef construction stopped in this zone at the beginning of our present interglacial stage, some 20,000 years ago. In addition, French Polynesian coral reefs and lagoons cover $15,047 \mathrm{~km}^{2}$ compared to the land area of $3,726 \mathrm{~km}^{2}$ (Andréfouët et al. 2005a).

The French Polynesian population is about 270,000, most of them reside in Tahiti and Moorea (75\%). The economy is dominated by tourism (220,000 tourist/year, 3,500 hotel units) and by black pearl production and export (very variable since 1985, culminating in 2000 with 11.6 tons of pearls per year, but less than 6 tons since then).

Coral reefs in French Polynesia are well surveyed in all five archipelagos (Salvat et al. 2008). Major cyclonic periods were during the El Nino events in 1983-83 (5 cyclones). Similarly, major coral bleaching events were in 1991 (10\% scleractinian mortality), 2002 and 2003 (sporadic and less mortality). The crown-of-thorns starfish, Acanthaster planci, plague infestations occurred from 1978-1982 and have again been active since 2006, mainly in the Society Islands.

Bryan (1953) listed 400 atolls in the world. All atolls are topped with coral reef construction growing on volcanic oceanic islands that have subsided. The definition of an atoll is very clear at the international level (Bryan 1953; Wiens 1962; Battistini et al. 1975): an emerged coral reef construction at high sea level without any volcanic rocks, often of annular form with a central lagoon. Most atolls (300) are in the Pacific while others are in the Indian Ocean and some in the Caribbean. 'Almost' atolls are those with some small remnants of volcanic relief that has not yet disappeared by subsidence (Bora Bora is an example in French Polynesia with an altitude of no more than $727 \mathrm{~m}$ ).

In French Polynesia, the list is 83 atolls, which are of different types (Fig. 1). Only one is elevated, Makatea, which is recognised internationally as an island well above sea level due to local uprising of the sea floor. Some of the lagoons have been completely filled in and covered with coconut exploitation or swamps: Aki Aki, Nukutavake, Tepoto nord and Tikei. The remaining atolls (78) are those with lagoons with or without a 'pass'. A pass is a large and deep notch in the atoll rim, more than a few meters deep by which there are permanent and major exchanges of water between the ocean and lagoon according to the tide. Other categories of connection between the ocean and lagoon are submerged reef flats on which sea waves break and run into the lagoon, and 'hoa', small channels which are cut into the conglomerate, old detritic consolidate platform on which are islets (or motu) with atoll vegetation. Submerged reefs are infrequent in French Polynesia, but the best, rare example, is on Mururoa on each side of the pass. Hoa are very frequent on open as well as closed lagoon atolls. Of course, the degree of water exchange between the sea and lagoon is dependent on how many there are of each connection category. A pass is by far the most important mechanism. For hoa, it depends on how 


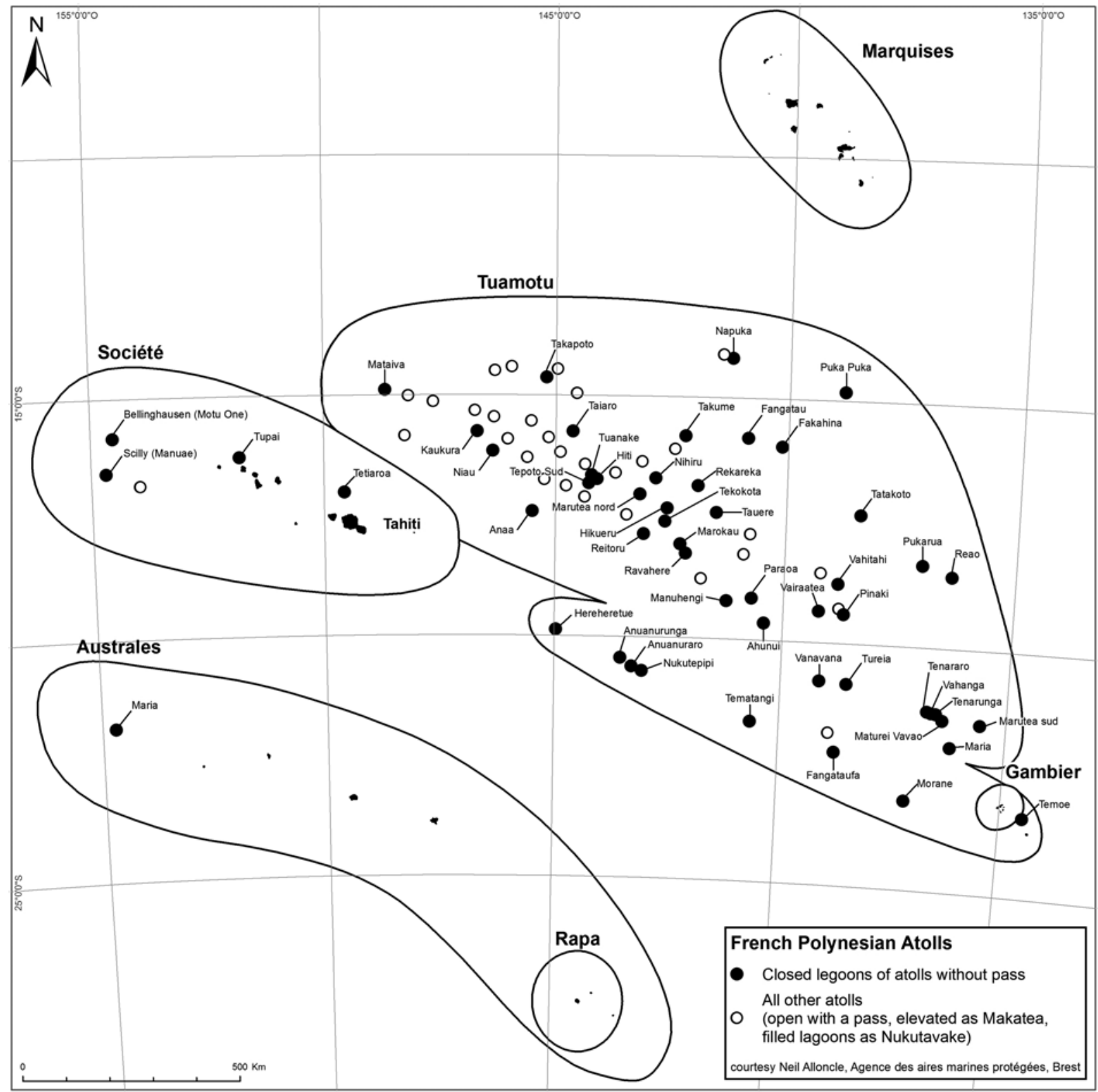

Fig. 1 A map of French Polynesia showing the high islands and atolls. The names of the 53 closed atolls without a pass are indicated

many, how large and how deep (but never more than 1 meter deep) they are and how frequently they carry water. It is important to recognise that some are always functioning, some only during swell conditions and others only during cyclonic events.

Among the 78 atolls with a lagoon in French Polynesia, 16 have one pass, eight have two passes and only one has three passes (Tahanea); most are closed atolls (53). After investigations of about 15 atolls between 1965 and 1970, open and closed (with and without a pass), we noted very high populations and the dominance of only a few species of benthic mollusks in closed lagoons with a very specific composition in each of them (Salvat 1971) compared to open lagoons. This study reported the lagoon faunal composition of 7 closed atolls. Since then we have investigated 11 more atolls and obtained information on 21 others. In total, we know the dominant benthic species in 39 out of the 53 lagoons with closed atolls. The aim of our study was to characterize the benthic fauna of each lagoon and to try to establish categorizations, if any. 


\section{Materials and methods}

Closed lagoons are characterised by only some macro species with very large populations (Salvat 1967): Tridacna maxima (Roding, 1798), Pinctada margaritifera (Linne, 1758), Pinctada maculata (Gould, 1850), Chama iostoma Conrad, 1837 (cited as C. imbricata in previous papers and as C. limbula Lamarck, 1819 in Paulay 1987) and Arca ventricosa Lamarck, 1819 or sometimes Barbatia foliata (cited as $A$. velata in previous papers) for Mollusca; Halodeima atra (Jaeger, 1833) for Holothuridea, Echinodermata; Acropora pulchra (Brook, 1891), branched coral and Porites lutea Edwards and Haime, 1860 for Scleractinian corals. In some lagoons, all these species were abundant whereas in most of them there was a particular combination among them, but the combinations were different from one lagoon to the other.

Mollusk densities of these species may exceed ten per square meter on hard substrate, as well for $H$. atra on the sand substrate. Acropora constitutes often expanded submarine branched forests in which T. maxima aggregated. Some quantitative data of these densities have been published on some closed atolls. On Reao (Salvat 1971, 1972), we noted the maximum density up to 224 T. maxima and 42 P. maculata per $\mathrm{m}^{2}$ with a total abundance in the border of the lagoon (0-6 m depth $-3.7 \mathrm{~km}^{2}$ on $39 \mathrm{~km}^{2}$ for the whole lagoon) of 11.5 million mollusks each. On Tatakoto 544 T. maxima per $\mathrm{m}^{2}$ have been reported as the maximum density (Gilbert et al. 2006). Those densities are the most significant in the world (Salvat 1971; Gilbert et al. 2006). Whereas on Takapoto lagoon $\left(77 \mathrm{~km}^{2}\right) 93$ mollusks have been identified in the lagoon, 4 of them $(P$. margaritifera, T. maxima, $C$. imbricata and $A$. ventricosa) are largely dominant and characteristic with 70 million individuals per 1,100 tons. Mean density on pinnacles were 5 and 18 per sq. $\mathrm{m}$ respectively for T. maxima and Arca ventricosa (Richard et al. 1979; Salvat and Richard 1985). T. maxima is so abundant in Fangatau lagoon that remote sensing data has been used to quantify the population (Andrefouët at al. 2005b).

Our objective was to survey the dominant mollusk species composition in each of the 53 closed lagoons. We failed to have data on 14 closed lagoons for which no academic publication or reports (grey literature) exist in our library (CRIOBE) or in the French Polynesian government offices (Service de la Pêche, Service de la Perliculture). For many of the 39 lagoons on which we have data, the density was noted, but for others, the qualitative investigation was sufficient due to the fact that when a species is present, its density is noticeable in every part of the lagoon. The species dominance in each lagoon was established either by our own investigations, from the literature (papers in periodicals or grey literature) or by inquiries. Irrespective of the data source, we did not consider sites of investigation near 'hoa' (a few decimeter of depth connection between ocean and lagoon): such was the case for atolls investigated by Adjeroud et al. (2000a, b). Even a small exchange between the sea and lagoon waters, even temporarily, can induce a more diverse benthic fauna and not always with the same dominance of species found to occur in $95 \%$ of the lagoon. Table 1 gives sources of our data and dates of investigations by different scientists in each lagoon and refers to the paper published or personal communication or unpublished observations.

\section{Results}

Table 1 lists the dominant and characteristic mollusks of all 39 closed lagoons investigated. Mollusk abundance is expressed on two scales: very abundant with densities as important as in previous examples (Réao, Tatakoto, Takapoto); and abundant with lower densities but with wide distribution all over the lagoon. We will consider these two categories together when expressing results and in the discussion. Table 1 also lists the perimeter of each atoll, its lagoon surface area, and the number of inhabitants, if any.

In some atolls, particularly closed, changes have been observed during recent decades due to natural events (Taiaro, Anaa) or both natural and anthropogenic (Mataiva). Therefore, it should be noted that the composition of the mollusk dominance in these lagoons is at the time of the investigations. In regards to $P$. margaritifera, we referred the our own data as mentioned in Table 1, but also to the 


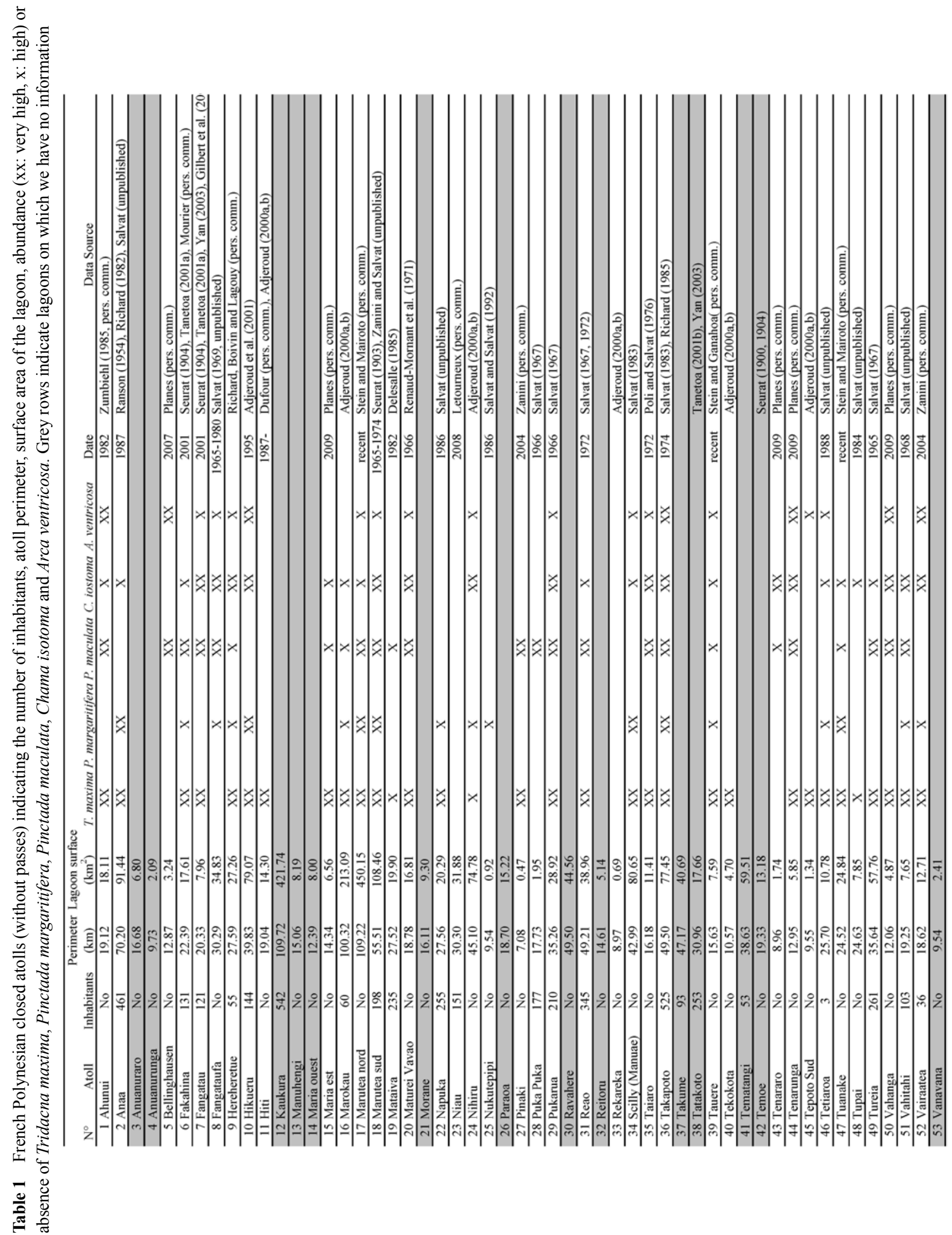


status of stock in the lagoons from early this century (Picquenot 1900) or more recently (Domard 1962; Zanini 1999) because our objective was to make a census of the natural dominant species not considering that, in some lagoons, the mother-of-pearl oyster bivalve was so exploited that the stock of the species disappeared; such is the case in Nukitipipi, and Nihiru.

Two closed lagoons do not contain any of these mollusks: Niau and Reka Reka. Large populations of $T$. maxima occur in 32 lagoons out of 39 , followed by $C$. iostoma (28 lagoons), P. maculata (25), A. ventricosa (20) and $P$. margaritifera (18). It should be noted that $T$. maxima is absent (or with only a few individuals, a non-dominant population) in only 7 lagoons: Bellingshausen, Fangataufa, Nukutipipi, Niau, Pukapuka, Reka Reka and Tenararo.

Although our study concerns the molluscan fauna of benthic communities, we noted that all lagoons have high densities of the holothurian $H$. atra, with a few exceptions (Niau as example). Nukutipipi, Reka Reka, Taiaro and Tenarunga have only colonies of Porites whereas all others also house Acropora and Porites. In Nukutipipi many dome patch reefs grew from the lagoon floor, no more than $18 \mathrm{~m}$ deep, but are all constituted of dead Acropora branches (Salvat and Salvat; 1992)

\section{Discussion}

\section{Low diversity but very high densities of some mollusks}

This study confirms observations and conclusions of previous papers of high densities in closed lagoons (atolls without passes) of a few mollusk species that find conditions suitable to dominate benthic fauna with large populations in a more or less confined environment (Salvat 1972). Previous research has mentioned the lack of fauna biodiversity in closed lagoons compared to open ones (Adjeroud et al. 2000b; Pante et al. 2006).

\section{Two atolls with lagoons without any mollusk popula- tions}

The two atolls, Niau and Reka Reka, with particularly low abundance of any mollusk species have special geomorphological characters explaining such a situation. Niau is 7 meters above sea level. This very shallow 32 $\mathrm{km}^{2}$ lagoon contains brackish waters and is inhabited by only three mollusks: Ctena bella (Conrad, 1837), Cerithium punctatum Bruguière, 1792 and Melanoides tuberculata Muller, 1774 (Salvat et al. in preparation). Niau is alone among the 39 closed atolls to be emerged, whereas the others are only 2-3 meters above the sea level with a lagoon connected with the ocean (except Taiaro, see below). There are no more living corals in the Niau lagoon. Reka Reka is a very small atoll with a residual lagoon, $0.7 \mathrm{~km}^{2}$, with a depth of less than 1 meter, in which there are only some colonies of Porites and one mollusk, Cypraea moneta (Adjeroud 2000b). These two lagoons, for different reasons, are in the process of being filled in, such that they will eventually lose their lagoons; similar to four other small atolls in French Polynesia (Aki Aki, Nukutavake, Tepoto nord and Tikei). This is a natural, geomorphological, evolution which occurred during the Holocene for these very small depressions inside the atolls

Table 2 Closed atoll lagoon groupings according to the composition of dominant mollusk species with large stocks

\begin{tabular}{ccccccl}
\hline T. maxima & $\begin{array}{c}\text { P. margari- } \\
\text { tifera }\end{array}$ & P. maculata & C. iostoma & A. ventricosa & Number & Atoll \\
\hline $\mathrm{X}$ & $\mathrm{X}$ & $\mathrm{X}$ & $\mathrm{X}$ & $\mathrm{X}$ & 5 & $\begin{array}{l}\text { Herehertue, Marutea Nord, Marutea Sud, } \\
\text { Takapoto, Tauere }\end{array}$ \\
\hline $\mathrm{X}$ & $\mathrm{X}$ & & $\mathrm{X}$ & $\mathrm{X}$ & 5 & Hikueru, Nihiru, Scilly, Tetiaroa, Vairaatea \\
\hline $\mathrm{X}$ & $\mathrm{X}$ & $\mathrm{X}$ & $\mathrm{X}$ & & 4 & Fakahina, Marokau, Vahitahi, Tuanake \\
\hline $\mathrm{X}$ & & $\mathrm{X}$ & $\mathrm{X}$ & $\mathrm{X}$ & 7 & $\begin{array}{l}\text { Ahunui, Fangatau, Maturei Vavao, Pukarua, } \\
\text { Taiaro, Tenarunga, Vahanga }\end{array}$ \\
\hline $\mathrm{X}$ & $\mathrm{X}$ & $\mathrm{X}$ & & 3 & Maria Est, Reao, Tureia \\
\hline $\mathrm{X}$ & $\mathrm{X}$ & & & 2 & Mataiva, Pinaki \\
\hline $\mathrm{X}$ & & & & 2 & Hiti, Tekokota \\
\hline & & & & 11 & $\begin{array}{l}\text { all others closed lagoons, each with an original } \\
\text { mollusk composition }\end{array}$ \\
\hline
\end{tabular}


and which were rapidly filled in by blocks and sand during strong events such as storms and cyclones.

Tridacna maxima, characteristic species, with huge populations in 41 lagoons among 53; from customary food to exported resource

If we exclude Niau and Reka Reka lagoons without any mollusks, 32 of the remaining 37 lagoons have very dense populations of Tridacna; the exceptions are Bellingshausen, Fangataufa, Nukutipipi, Pukapuka and Tenararo. If we consider the 14 lagoons not included because of a lack of or poor data in regards to the mollusk fauna, we can observe there are large stocks of Tridacna in the 9 following lagoons: Anuanuraro, Kaukura, Manuhengi, Maria Ouest, Paraoa, Reitoru, Tatakoto, Tematangui and Temoe. In total, the giant clam is abundant and characteristic in 41 closed lagoons among the 53. For 5, we do not know the status of any stock (Anuanurunga, Morane, Ravahere, Takume and Vanavana) and for 7 we know that there are no important stocks (Bellinghausen, Fangataufa, Niau, Nukutipipi, Pukapuka, Reka Reka and Tenararo). In these closed lagoons, water temperatures are more elevated than in the ocean and dissolved oxygen is much lower. The genus Tridacna has an advantage in terms of nutrition and oxygen exchange due to the physiology and metabolism of its symbiosis with the zooxanthellae. The extreme abundances of Tridacna in so many closed lagoons in French Polynesia is an major resource for the inhabitants. In the 1960s, the customary food of Tridacna meat made up to $400 \mathrm{~g}$ per day per person (Salvat 1967). Tridacna now has an exploitable economic value in some atolls which export the flesh of the giant clam to the Papeete market because it is a traditional food of Polynesians.

\section{Pinctada margaritifera, a characteristic species in half closed lagoons and an economic resource for two cen- turies}

P. margaritifera is a species which was intensively collected for the button industry from the early nineteenth century until the 1970s, when the pearl industry was promoted. We reported that 18 of the 39 investigated closed lagoons were housing this mollusk. For 14 lagoons, we do not have enough data to characterize the dominant mollusks, but we know that the bivalve occurs in 4 of them (Anuanuraro, Kaukura, Ravahere and Takume), constituting 22 out of 43 . Closed atolls and their lagoons were the major producers: Hikueru, Marutea sud, Takapoto and Takume, but also some open atolls (with passes) such as Takaroa or Manihi or Gambiers islands (Hervé 19331934; Domard 1962,; Zanini and Salvat 1999; Salvat et al. 2008). From 1900 to 1970, around 40,000 tons have been exported, but in the previous century, it was probably 5 to 10 times that amount. We observed that $P$. margaritifera and $P$. maculata were not always co-occurring. They occur together in only 10 lagoons. The second one occurs in 10 lagoons where the first one is absent. The reverse occurs in 8 lagoons for $P$. margaritifera occurring where P. maculata is absent.

\section{Categorisation of closed lagoons according to their dominant mollusk species}

Three mollusks, C. iostoma, P. maculata and A. ventricosa, are respectively abundant with high densities in 28, 25 and 20 lagoons (populations listed in Table 1). The number of possible assemblages (collections) of the five mollusks is 31 , but some do not occur. If we consider the possibility in a lagoon to house only one of the 5 species (as a large and characteristic population), such a case occurs for T. maxima in Hiti and Tekokota and for $P$. margaritifera in Nukutepipi (note: over exploited stock) but it occurs nowhere for the 3 other species which may be present and abundant in some lagoons but not alone. In total, 12 categories of collection did not occur. For example, there is no lagoon housing the assemblage $P$. margaritifera, $P$. maculata and $A$. ventricosa, nor the assemblage T. maxima, P. maculata and A. ventricosa. A total of 19 categories of assemblages occurred of which 11 are original, occurring in only one lagoon, and 7 categories would be grouped for a total of 28 lagoons. Table 2 shows these assemblages and the lagoon grouping. The assemblages with large populations of all 5 species occur in 5 atolls, but it is not the most important group, which is the one where all species occurred except $P$. margaritifera in 7 lagoons. The general trend is: the larger the lagoon, the larger the diversity of the mollusk composition of characteristic, dominant species; and, vice versa, the smaller the lagoon, the smaller the collection of 
mollusks. But there is no clear correlation between lagoon surface and the assemblage of mollusks.

\section{Conclusions}

We investigated the lagoon mollusk fauna of 39 closed lagoons among 53 existing closed atolls (without a pass) in French Polynesia, considering species whose stocks are dominant with high densities. Such a qualitative and quantitative distribution of the fauna in terms of abundance and dominance, is specific to closed atolls. These atolls without a pass (as opposed to open atolls with large exchanges of waters between ocean and lagoon), have lagoons with waters isolated from the ocean: submerged reefs are non-existent and shallow channels ('hoa' between 'motu') do not permit major water exchanges. These lagoons have been large 'mesocosms' i.e., large and natural laboratories with an evolution of their own communities since 2000-4000 years ago when the sea level decreased by about one meter from the maximal level. During this interglacial period, these atolls with confined lagoons began to emerge.

We analysed the molluscan fauna of these atolls for 5 species whose stocks and densities are dominant and among the largest in the marine environment in terms of individuals and biomass. The giant clam of French Polynesia, Tridacna maxima is the characteristic species of these closed lagoons with large stocks in 41 lout of 53 lagoons. The mother-of-pearl oyster, Pinctada margaritifera, is another characteristic species; its abundance allowed the exploitation of its stock for one and a half centuries and is now an economic resource for the black pearl industry. The 3 other species (Pinctada maculata, Chama iostoma and Arca ventrisoca) have also abundant stocks in many lagoons. Considering the assemblage categories of these 5 species (in theory 31 possibilities), only 7 occurred, grouping 20 lagoons among 39, but without any apparent correlation to lagoon surfaces areas. Only 7 atolls show the same collection of dominant mollusk species with large populations (Ahunui, Fangatau, Maturei Vavao, Pukarua, Taiaro, Tenarunga and Vahanga): all five species except $P$. margaritifera.

This study must be continued until we have data on the
14 closed lagoons for which no publication or report is available in French Polynesian offices and institutions. There are many assemblage categories from among the 31 possibilities that we have considered for the 5 dominant species. Some closed lagoons have similar compositions, however, many more have original and unique mollusk communities. The conclusion from this study is that we are very far from understanding why such species are so abundant in one lagoon and not in the other. In order to progress, we need to understand the physiology and metabolism of each species better. All of them are not as unique as Tridacna with its symbiotic zooxanthellae. However, the tolerance to temperature and dissolved oxygen is important for these species. Yet why these ones and not taxonomically related ones? It is also required to look at: the variability of mollusk composition and stocks in some lagoons over time, it is important to consider how the defined stock of a species can occupy and dominate space, how a species can maintain dominance, how it can recover after a catastrophic event (natural or anthropogenic such as depleted stock by over exploitation), the role and importance of the first occupier, and consider the connectivity between lagoon stocks for these species. These questions will require both field observation and experimentation.

\section{Acknowledgments}

Thanks to IFRECOR Polynésie (Annie Aubanel) who contributed to the research and to the "Centre de Recherches Insulaires et Observatoire de l'Environnement" CRIOBE-EPHE in Moorea (Serge Planes and Yannick Chancerelle). Thanks to all colleagues who spent time to provide information on different atolls (Mehdi Adjeroud, Neil Alloncle, Raynal Boivin, Sophie Brugneaux, Eric Conte, Bruno Delesalle, René Galzin, Ropati Ganahoa, Elodie Lagouy, Jean Letourneux, Johan Mourier, Goerges Richard, Arsène Stein, Mainui Tanetoa, Jean Trondle, Jean Marc Zanini and Paul Zumbiehl) and especially to Christian Monier, Service de la pêche à Papeete, who helped me for many contacts. This paper is in homage to our colleague Professor Kiyoshi Yamazato, who gave so much of energy for the development of coral reef research 
in Japan with an important involvement in international cooperation. This paper is a souvenir of agreement of cooperation between the University of the Ryukyus and Ecole Pratique des Hautes Etudes in Moorea, French Polynesia.

\section{References}

Adjeroud M, Andréfouët S, Galzin R, Harmelin-Vivien M, Kulbicki M, Mou-Tham G (2000a) Premiers résultats concernant le benthos et les poissons au cours des missions Typatoll. Doc Sci Tech IRD 3: 1-21

Adjeroud M, Andréfouët S, Payri C, Orempüller J, (2000b) Physical factors of differentiation in macrobenthic communities between atoll lagoons in the Central Tuamotu Archipelago (French Polynesia). Mar Ecol Prog Ser 196: 25-38

Adjeroud M, Andréfouët S, Payri C (2001) Mass mortality of macrobenthic communities in the lagoon of Hikueru atoll (French Polynesia). Coral Reefs 19: 287-291

Andréfouët S, Chauvin C, Spraggins S, Torres-Pulliza D, Kranenburg C (2005a) Atlas des récifs corallines de Polynésie française. Centre IRD de Nouméa, New Caledonia

Andréfouët S, Gilbert A, Yan L, Remoissenet G, Payri C, Chancerelle Y (2005b) The remarkable population size of the endangered clam Tridacna maxima assessed in Fangatau Atoll (Eastern Tuamotu, French Polynesia) using in situ and remote sensing data. ICES J Mar Sci 62: 1037-1048

Battistini R, Bourrouilh F, Chevalier JP, Coudray J, Denizot M, Faure G, Fischer JC, Guilcher A, Harmelin-Vivien M, Jaubert J, Laborel J, Monyaggioni L, Masse JP, Mauge L, Peyro-Clausade M, Pichon M, Plante R, Plaziat JC, Plessis Y, Richard G, Salvat B, Thomassin B, Vasseur P, Weydert $\mathrm{P}$ (1975) Eléments de terminologie récifale indopacifique. Téthys 7: 1-111

Bonneville A (2009) French Polynesia, Geology. In: Gillespie RG, Clague DA (eds) Encyclopedia of islands. University of California Press, Berkeley, pp 338-343

Bryan Jr EH (1953) Check list of atolls. Atoll Res Bull 19: $1-38$

Delesalle B (1985) Mataiva, Tuamotu Archipelago. Proc Fifth Int Coral Reef Congr 1: 269-322

Domard J (1962) Les bancs nacriers de la polynésie française (leur exploitation, leur conservation, leur reconstitution).
Service de l'élevage et des pêches, Papeete

Gilbert A, Andréfouët S, Yan L, Remoissenet G (2006) The giant clam Tridacna maxima communities of three French Polynesia islands: comparison of their population sizes and structures at early stages of their exploitation. ICES J Mar Sci 63: 1573-1589

Hervé F (1933-1934) L'huître perlière et la perle dans les lagons de l'Archipel des Tuamotu. Bulletin de l'Agence Générale des Colonies, Paris: 1373-1431, 112-170

Paulay G (1987) Biology of Cook Islands bivalves. Part I. Heterodont families. Atoll Res Bull 298: 1-32

Picquenot FV (1900) Géographie physique et politique des établissements français d'Océanie. A Challamel, Paris

Pante E, Adjeroud M, Dustan P, Penin L, Schrimm M (2006) Spatial patterns of benthic invertebrate assemblages within atoll lagoons: importance of habitat heterogeneity and considerations for marine protected area design in French Polynesia. Aquat Living Resour 19: 207-217

Poli G, Salvat B (1976) Etude bionomique d'un lagon d'atoll totalement fermé: Taiaro. Cahiers du Pacifique 19: 227251

Ranson G (1954) Observations sur l'eau lactescente du lagon de l'île Anaa (Tuamotu). CR Acad Sci Paris 238: 2330-2331

Renaud-Mornant J, Salvat B, Boissy C (1971) Macrobenthos and meiobenthos from the closed lagoon of a polynesian atoll: Maturei Vavao (Tuamotu). Biotropica 3: 36-55

Richard G (1982) Bilan quantitative et premières données de production de Cardium fragum (Mollusca, Bivalvia) dans le lagon de Anaa. Malacologia 22: 347-352

Richard G (1985) Richness of the great sessile bivalves in Takapoto lagoon. Proc Fifth Int Coral Reef Congr 1: 368371

Richard G, Salvat B, Millous O (1979) Mollusques et faune benthique du lagon de Takapoto. J Soc Océanistes 35: 5968

Salvat B (1967) Importance de la faune malacologique dans les atolls polynésiens. Cahiers du Pacifique 11: 7-49

Salvat B (1969) Dominance biologique de quelques mollusques dans les atolls fermés (Tuamotu, Polynésie). Phénomène récent - conséquences actuelles. Malacologia 9: 187-189

Salvat B (1971) La faune benthique du lagon de l'atoll de Reao. Cahiers du Pacifique 16: 30-109

Salvat B (1972) Evaluation quantitative totale de la faune benthique de la bordure lagunaire d'un atoll de la Polynésie française. CR Acad Sci Paris 272(D): 211-214

Salvat B (1983) La faune benthique du lagon de l'atoll de Scilly, Archipel de la Société. J Soc Océanistes 77: 5-15 
Salvat B, Richard G (1985) Takapoto atoll, Tuamotu archipelago. Proc Fifth Int Coral Reef Congr 1: 323-278

Salvat B, Salvat F (1992) Nukutipipi Atoll, Tuamotu Archipelago: geomorphology, land and marine flora and fauna and interrelationships. Atoll Res Bull 357: 1-43

Salvat B, Aubanel A, Adjeroud M, Bouisset P, Calmet D, Chancerelle Y, Cochennec N, Davies N, Fougerouse A, Galzin R, Lagouy E, Lo C, Monier C, Ponsonnet C, Remoissenet G, Schneider D, Stein A, Tatarata M, Villiers L (2008) Le suivi de l'état de santé des récifs coralliens de Polynésie française et leur récente évolution. Revue d'écologie (Terre et Vie) 62: 145-177

Seurat LG (1900) Observations sur la structure de l'île Temoe (Crescent). Journal Officiel des Etablissements Français de l'Océanie, Papeete: 1-8

Seurat LG (1903) Observation sur la structure, la faune et la flore de l'île Marutea du Sud (Archipel des Tuamotu). Journal Officiel des Etablissements Français de l'Océanie, Papeete: $1-18$

Seurat LG (1904) Observations sur quelques îles orientales de l'Archipel des Tuamotu. Journal Officiel des Etablissements Français de l'Océanie, Papeete: 1-11

Tanetoa M (2001a) Rapport de Mission OD N89/01/SRM du 09/03/2001, Fangatau, Fakahina, Puka Puka et Napuka.
Service de la Pêche, Papeete, Tahiti

Tanetoa M (2001b) Rapport de Mission OD N¹03/01/SPE du 30-05-2001, Hao, Amanu, Tatakoto, Reao, Pukarua. Service de la Pêche, Papeete, Tahiti

Wiens HJ (1962) Atoll environment and ecology. Yale University Press, New Haven and London

Yan L (2003) Rapport final relatif à la mise au point de protocoles de collectage, de transport, d'élevage et de repeuplement de bénitiers à Tatakoto et Fangatau. Service de la pêche, convention ${ }^{\circ} 2^{\circ} 2176$ du 6 novembre 2002, Papeete, Tahiti

Zanini JM (1999) Stocks naturels de nacres, Pinctada margaritifera, de Polynésie française. Thèse Doctorat EPHE, CRIOBE, Moorea, French Polynesia

Zanini JM, Salvat B (1999) Assessment of deep water stocks of pearl oysters at Takapoto (Tuamotu Archipelago, French Polynesia). Coral Reefs 19: 83-87

Zumbiehl P (1985) Un atoll et un rêve. Albin Michel, Paris

Received: 29 September 2009

Accepted: 27 October 2009

C Japanese Coral Reef Society 